\title{
Experimental Study on Shear Capacity of Waste Fiber Recycled Concrete Shear Wall
}

\author{
Xiaohu $\mathrm{Li}^{1 *}$, Lei $\mathrm{Li}^{1}$ \\ ${ }^{1}$ School of Civil Engineering and Architecture, Zhengzhou University of Aeronautics, Zhengzhou, China
}

\begin{abstract}
In this paper, the shear capacity of waste fiber recycled concrete shear wall (FCSW) is studied by cyclic loading tests on 9 specimens. The failure of the specimens under low cycle cyclic loading is analyzed. The influence of waste fiber content, recycled aggregate content and axial compression ratio on the shear capacity of shear wall is studied. The results show that: the larger the volume ratio of waste fiber is, the higher the shear bearing capacity of shear wall is; the addition of recycled coarse aggregate will reduce the shear capacity of shear wall; the shear capacity of shear wall increases with the increase of axial pressure. On the basis of relevant specifications, the calculation formula of in-plane shear capacity of waste fiber recycled concrete shear wall is proposed considering the influence of waste fiber on shear capacity. By comparing with the test results, it can be found that the two formulas are in good agreement. The conclusion of the study can provide reference for the design of waste fiber recycled concrete shear wall.
\end{abstract}

\section{Introduction}

With the rapid development of Chinese urbanization, a large number of waste buildings have been demolished. It resultied in more and more construction waste such as waste concrete. At present, there are serious waste of land resources and environmental pollution in the treatment of construction waste in China[1]. In order to make full use of waste concrete and other construction waste, domestic and foreign scholars began to use waste fiber concrete to replace part or all of the concrete coarse aggregate to make recycled concrete, and studied its mechanical properties and components [2 5]. Due to the decrease of strength, toughness and crack resistance of recycled aggregate concrete, its application in practical engineering is limited. According to the research results at home and abroad, the incorporation of fiber can improve the mechanical properties of recycled aggregate concrete [6 8]. The recycled waste fiber is processed, manufactured and mixed into recycled aggregate concrete for reuse, which not only solves the problems of resource waste and environmental pollution, but also produces better economic and social benefits.

At present, many scholars at home and abroad began to study the waste fiber recycled concrete, mainly focusing on the material and structural performance. Zhou[9 12] studied the constitutive problems such as splitting tensile strength and compression damage of waste fiber recycled concrete, and the flexural performance of waste fiber recycled concrete beam. The test results show that the splitting tensile strength of concrete can be improved to a certain extent by adding appropriate amount of waste fiber; the uniaxial compression damage test of prism specimen is carried out. In the test, with the increase of strain, the damage variable of waste fiber recycled concrete also increases. In the bending process of waste fiber recycled concrete beam, the ductility and bearing capacity of the beam are improved. Wang[13] studied the seismic performance of fiber reinforced recycled concrete frame joints, and the results show that: the incorporation of fiber improves the bearing capacity and seismic performance of frame joints. Wang[14] studied the carbonation performance of waste fiber recycled concrete through rapid carbonation test. The results show that: the addition of waste fiber can reduce the carbonation depth. At present, the research on the waste fiber recycled concrete shear wall is still relatively few at home and abroad. In this paper, the shear capacity of waste fiber recycled concrete shear wall under low cycle cyclic load is obtained through theoretical analysis and test. The shear bearing capacity formula of waste fiber recycled concrete shear wall is proposed by theoretical analysis method. The research results can provide reference for the design of waste fiber recycled concrete shear wall, and lay the foundation for the future application of waste fiber recycled concrete shear wall in practical engineering.

\section{General situation of constitutive test}

Recycled coarse aggregate takes concrete with original strength of $\mathrm{C} 40$ as raw material. The concrete is artificially crushed and then made into continuously graded coarse aggregate with a maximum diameter of 25 $\mathrm{mm}$. The waste fiber is made from waste fabric as shown in Figure 1. 

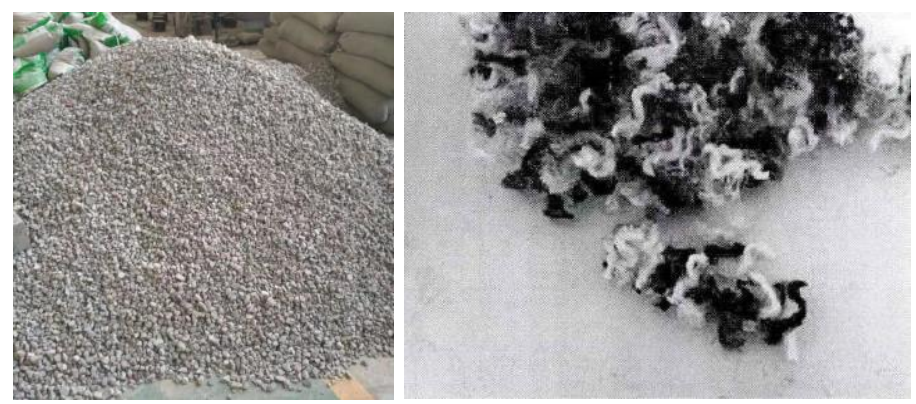

Figure 1. Coarse aggregate and waste fiber

The test scheme of concrete test block is determined according to the type of shear wall. Three cubes with dimensions of $150 \mathrm{~mm} \times 150 \mathrm{~mm} \times 150 \mathrm{~mm}, 3$ prism concrete specimens. The strength, uniaxial tensile stressstrain curve and uniaxial compression stress-strain curve of concrete were measured. The test loading device is blocks with dimensions of $150 \mathrm{~mm} \times 150 \mathrm{~mm} \times 300$ shown in Figure. 2. The values of measured test data $\mathrm{mm}$ and 3 tensile test blocks with dimensions of $100 \mathrm{~mm}$ after processing are shown in Table 1.

$\times 100 \mathrm{~mm} \times 370 \mathrm{~mm}$ are made for each type of
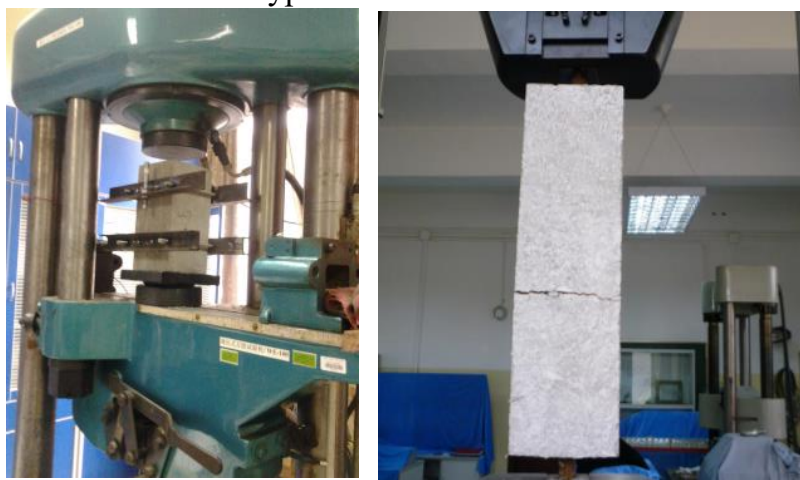

Figure. 2 Test device for compressive strength and tensile strength of concrete

Table 1. Test strength values of waste fiber recycled concrete

\begin{tabular}{ccccccc}
\hline $\begin{array}{l}\text { Num } \\
\text { ber }\end{array}$ & $\begin{array}{c}\text { Concrete } \\
\text { strength }\end{array}$ & $\begin{array}{l}\text { Volume ratio } \\
\text { of waste } \\
\text { fiber/\% }\end{array}$ & $\begin{array}{l}\text { Replacement rate } \\
\text { of regenerated } \\
\text { coarse aggregate/\% } \%\end{array}$ & $\begin{array}{l}\text { Cubic } \\
\text { compressive } \\
\text { strength/MPa }\end{array}$ & $\begin{array}{l}\text { Tensile } \\
\text { strength/ } \\
\mathrm{MPa}\end{array}$ & $\begin{array}{l}\text { Elastic } \\
\text { modulus } \\
/ \mathrm{kN} / \mathrm{mm}^{2}\end{array}$ \\
\hline 1 & $\mathrm{C} 40$ & 0 & 0 & 40.47 & 4.08 & 32.51 \\
2 & $\mathrm{C} 40$ & 0 & 50 & 39.12 & 3.73 & 26.81 \\
3 & $\mathrm{C} 40$ & 0.08 & 50 & 41.68 & 3.87 & 27.65 \\
4 & $\mathrm{C} 40$ & 0.12 & 50 & 43.98 & 4.36 & 27.98 \\
5 & $\mathrm{C} 40$ & 0.16 & 50 & 40.82 & 4.48 & 28.62 \\
6 & $\mathrm{C} 40$ & 0.08 & 0 & 40.36 & 4.12 & 32.68 \\
7 & $\mathrm{C} 40$ & 0.08 & 100 & 37.96 & 3.56 & 25.66 \\
\hline
\end{tabular}

\section{Scheme design}

\subsection{Specimen design}

In this paper, nine specimens of waste fiber recycled concrete shear wall are designed. Taking the common
C40 reinforced concrete shear wall as a reference, the influence of waste fiber volume ratio, recycled aggregate volume ratio and axial compression ratio on the shear capacity of shear wall is studied. The test parameters are shown in Table 2.

Table 2. Parameter design of FCSW

\begin{tabular}{lccccc}
\hline Number & $\begin{array}{c}\text { Strength } \\
\text { grade of } \\
\text { concrete }\end{array}$ & $\begin{array}{c}\text { volume ratio } \\
\text { of waste } \\
\text { fiber } \%\end{array}$ & $\begin{array}{c}\text { Recycled aggregate } \\
\text { replacement ratio } \\
/ \%\end{array}$ & $\begin{array}{c}\text { Axial } \\
\text { compression } \\
\text { ratio }\end{array}$ & $\begin{array}{c}\text { Vertical } \\
\text { load / N }\end{array}$ \\
\hline FCSW1 & C40 & 0 & 0 & 0.2 & 390390 \\
FCSW2 & C40 & 0 & 50 & 0.2 & 390390 \\
FCSW3 & C40 & 0.08 & 50 & 0.2 & 390390
\end{tabular}




\begin{tabular}{lllccc} 
FCSW4 & C40 & 0.12 & 50 & 0.2 & 390390 \\
FCSW5 & C40 & 0.16 & 50 & 0.2 & 390390 \\
FCSW6 & C40 & 0.08 & 0 & 0.2 & 390390 \\
FCSW7 & C40 & 0.08 & 100 & 0.2 & 390390 \\
FCSW8 & C40 & 0.12 & 50 & 0.3 & 585585 \\
FCSW9 & C40 & 0.12 & 50 & 0.4 & 780780 \\
\hline
\end{tabular}

The reinforcement is HRB335, the diameter of longitudinal reinforcement is $16 \mathrm{~mm}$, and the diameter of stirrup is $8 \mathrm{~mm}$. The shear wall specimens are mainly composed of loading beam, shear wall and foundation. The size of the loading beam (length $\times$ width $\times$ height) is $1000 \mathrm{~mm} \times 230 \mathrm{~mm} \times 200 \mathrm{~mm}$, the size of shear wall is
$1000 \mathrm{~mm} \times 130 \mathrm{~mm} \times 1900 \mathrm{~mm}$, and the size of foundation is $2000 \mathrm{~mm} \times 500 \mathrm{~mm} \times 500 \mathrm{~mm}$. In order to compare and study the changes of various factors, the size and reinforcement of each specimen are the same, as shown in Figure 3.

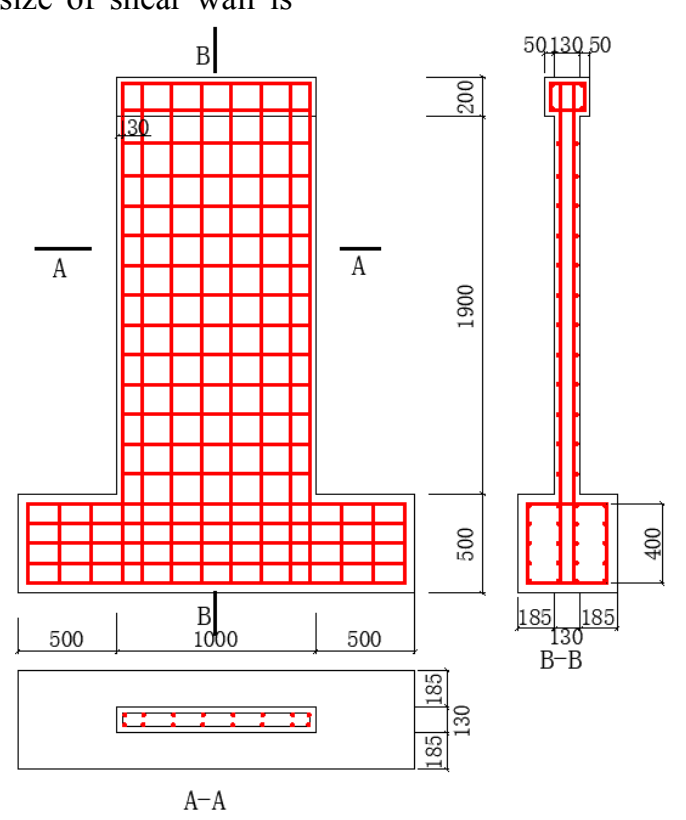

Figure 3 Specimen size and reinforcement drawing (unit: $\mathrm{mm}$ )

online system was used to carry out low cycle cyclic loading on specimens of FCSW. The loading diagram of the test device is shown in Figure 4.

\subsection{Experimental test.}

In the experiment, the electro-hydraulic servo loader

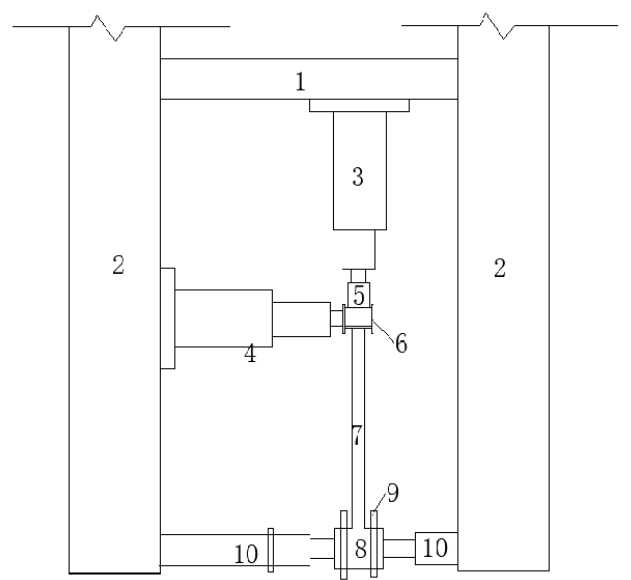

1 - Frame beam 2 - Reaction wall 3 - Vertical hydraulic jack

4 - Horizontal actuator 5 - Distribution beam 6 - Loading beam

7 - Shear wall 8 - Foundation beam 9 - Ground anchor bolt 10 - Hand Jack

Figure 4. Loading diagram of test device 


\section{$4 \quad$ Experimental phenomena and failure modes}

The low cycle cyclic loading test of FCSW specimens is similar, which can be roughly divided into four stages: elastic stage, crack development stage, yield stage and failure stage. The crack development and failure mode of shear wall specimens are shown in Figure 5.

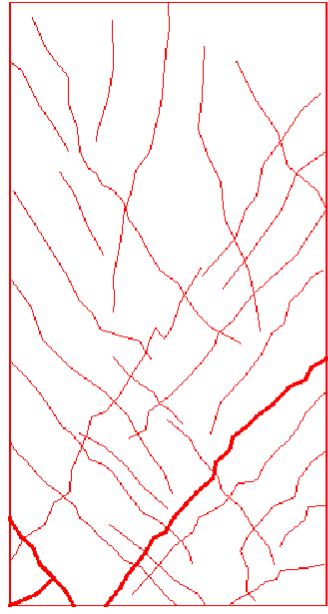

(a)FCSW1

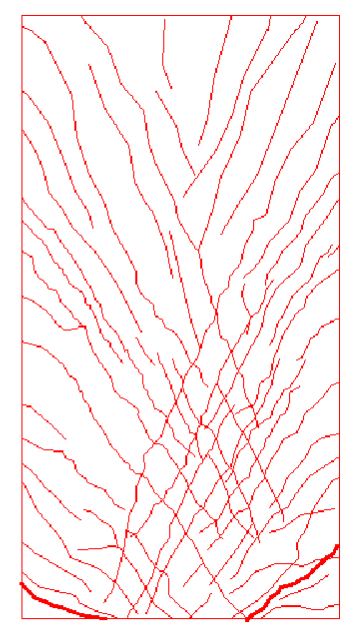

(b)FCSW6

Figure 5. Distribution and failure mode of wall cracks

Elastic stage: the wall is basically in elastic state without obvious phenomenon.

Crack development stage: with the increase of load, cracks first appear at the root of the wall tensile zone and continue to develop. When the loading continues, the inclined cracks appear at the position near the top of the foundation and extend to the middle of the wall.

Yield stage: the cracks in the corner concrete become wider, and the fibers in the concrete begin to play a role. But under the same load, the displacement variable increases. The specimens yield obviously. The yield phenomenon of shear wall specimens without waste fiber is not obvious.

Failure stage: the corner concrete is crushed by large blocks, and the fiber is broken. The reinforcement at the corner of the wall yielded and the bearing capacity of the wall decreased sharply.

It can be seen from Figure 5 that when the shear failure occurs in the shear wall specimen FCSW6, the number of inclined cracks is more, and the through cracks are relatively short. When the shear wall bottom is damaged, the concrete spalling is serious and the failure is ductile; the distribution of cracks in the shear wall specimen FCSW1 is relatively sparse, but the through cracks are relatively long. Through comparison, it can be found that the incorporation of waste fiber can prevent the formation of cracks to a certain extent.

\section{$5 \quad$ Analysis of shear capacity of FCSW}

\subsection{Influence of various factors on shear capacity of FCSW}

Based on the test results of specimens FCSW2, FCSW3, FCSW4 and FCSW5, Figure 6 (a) shows the change of shear capacity of shear wall specimens with volume fraction of waste fiber when the replacement rate of recycled aggregate is $50 \%$. It can be seen from the figure that the more the waste fiber volume content, the greater the shear bearing capacity of the shear wall specimen.

Comparing the test results of FCSW6, FCSW3 and FCSW7, Figure 6 (b) shows the change of shear capacity of shear wall specimens with recycled coarse aggregate content when the volume ratio of waste fiber is $0.08 \%$. It can be seen from the figure that when the content of recycled aggregate increases from $0 \%$ to $50 \%$, the shear capacity of shear wall specimen decreases by $4.85 \%$; when the content of recycled aggregate increases from $50 \%$, the shear bearing capacity of shear wall specimen decreases by $3.69 \%$.

Comparing the test results of FCSW4, FCSW8 and FCSW9, Figure 6 (c) shows the variation of shear capacity of shear wall specimens with axial compression ratio. It can be seen from the figure that the shear bearing capacity of shear wall specimens increases with the increase of axial compression ratio. When the axial compression ratio changes from 0.2 to 0.3 , the shear capacity increases by $10.4 \%$; when the axial compression ratio changes from 0.2 to 0.3 , the shear bearing capacity increases by $13.5 \%$. 


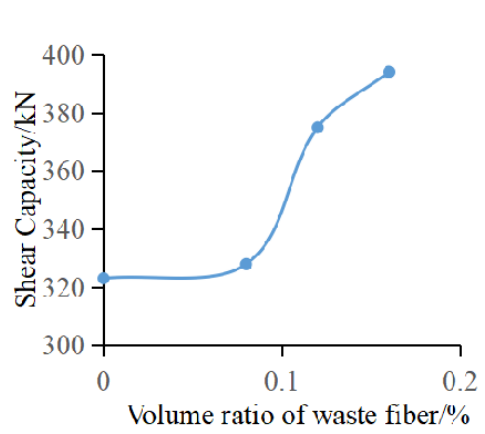

(a) Effect of volume ratio of waste fiber

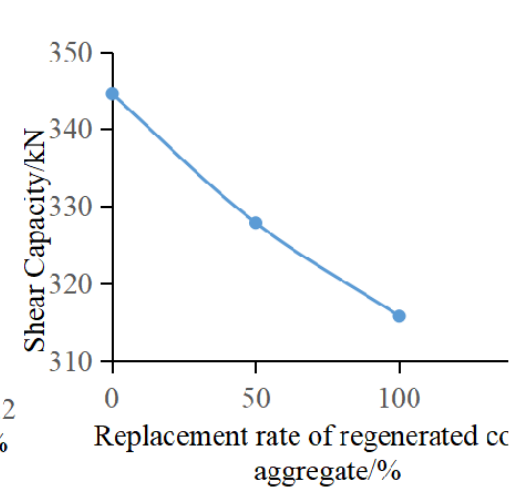

(b) Effect of replacement rate of regenerated coarse aggregate

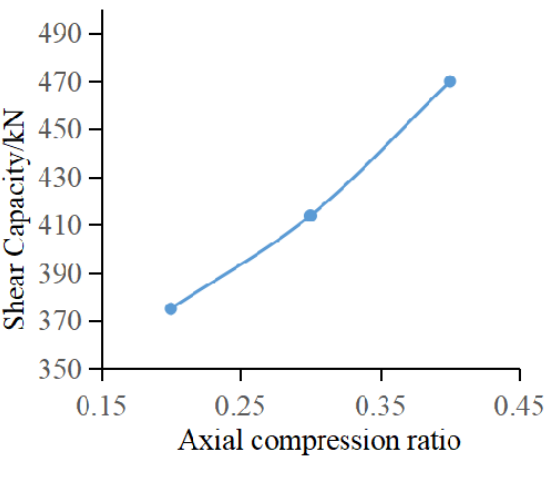

(c) Effect of axial compression ratio

Figure 6. Influence of various factors on shear capacity

\subsection{Calculation of shear capacity of FCSW}

The incorporation of waste fiber and replacement of natural coarse aggregate with recycled fiber make the material performance of recycled concrete with waste fiber different from that of ordinary reinforced concrete. Therefore, the structural performance of FCSW is different from that of ordinary reinforced concrete shear wall. According to the provisions of code for design of concrete structures (GB 50010-2010) and technical specification for fiber reinforced concrete structures (CECS 38:2004), and considering the influence of waste fiber and recycled concrete on shear capacity of shear wall, the shear capacity of FCSW $V_{u}$ can be divided into two parts: Shear capacity of concrete $V_{c}$ and horizontal reinforcement concrete resistance $V_{s}$. The concrete strength is the recycled aggregate concrete strength considering the recycled aggregate content and multiplied by the influence coefficient of waste fiber. Therefore, the shear capacity of shear wall can be calculated according to the following formula:

$$
\begin{aligned}
& V_{u}=V_{c}+V_{s} \\
& V_{c}=\frac{1}{\lambda-0.5}\left(0.5 f_{t} b h_{w 0}+0.13 N \frac{A_{w}}{A}\right) \\
& V_{s}=f_{y h} \frac{A_{s h}}{s} h_{w o}
\end{aligned}
$$

Where $\lambda$ is shear span ratio, $\lambda=M / V h_{w 0},(\lambda$ is 1.5 when $\lambda$ is less than $1.5, \lambda$ is 2.2 when $\lambda$ is greater than 2.2), $f_{t}$ is design value of axial tensile strength of concrete, $b$ is Section width, $h_{w 0}$ is effective height of section, $A_{w}$ is Area of shear wall Web (When the crosssection is rectangular $\left.A_{w}=A\right), f_{y h}$ is the yield strength of horizontal stirrups, $A_{s h}$ is the section area of horizontal stirrup at the same section of wall limb, $s$ is spacing of horizontal stirrups, $N$ is axial force(When $N>0.2 f_{t} b h$, take $N=0.2 f_{t} b h$ ).

According to the test data [15], it can be found that the ultimate shear capacity increases with the increase of waste fiber volume content in a certain range. Therefore, the influence coefficient of waste fiber on shear capacity of inclined section $\beta_{v}$ is introduced. The formula of influence coefficient is obtained by fitting test data and applied to the design of recycled concrete shear wall. The shear capacity of FCSW can be expressed by formula (4): $V_{u}=\frac{1}{\lambda-0.5}\left[0.5 f_{t} b h_{w 0}\left(1+\beta_{v}\right)+0.13 N \frac{A_{w}}{A}\right]+f_{y h} \frac{A_{s h}}{s} h_{w 0}$

$\beta_{v}=25 \rho_{f}$

Where $\beta_{v}$ is the influence coefficient of waste fiber on shear capacity of inclined section, $\rho_{f}$ is volume ratio of waste fiber, and $\rho_{f}=0 \sim 0.16 \%$.

\subsection{Comparison of calculated and measured shear capacity}

The calculated and measured values of each specimen of waste fiber recycled concrete shear wall are shown in Table 3.

Table 3 Comparison of calculated and measured values of each specimen

\begin{tabular}{cccc}
\hline Number & $\begin{array}{c}\text { Measured values / } \\
\mathrm{kN}\end{array}$ & $\begin{array}{c}\text { Calculated values / } \\
\mathrm{kN}\end{array}$ & $\begin{array}{c}\text { Measured value / } \\
\text { Calculated value }\end{array}$ \\
\hline $\mathrm{RCS} 1$ & 354.99 & 314.15 & 1.13 \\
$\mathrm{RCS} 2$ & 322.95 & 288.35 & 1.12
\end{tabular}




$\begin{array}{ll}\text { RCS3 } & 307.86 \\ \text { RCS4 } & 374.96 \\ \text { RCS5 } & 394.09 \\ \text { RCS6 } & 344.57 \\ \text { RCS7 } & 315.76 \\ \text { RCS8 } & 413.86 \\ \text { RCS9 } & 469.87 \\ \text { seen from table 3 that the average value of } \\ \text { an the measured value and the calculated } \\ \text { calculated value is conservative. }\end{array}$

\section{Conclusion}

In this paper, nine FCSW specimens are tested under low cyclic loading test, and the method of theoretical analysis is used to study the calculation of shear capacity of FCSW.The following conclusions can be drawn.

(1) The influence of various factors on the shear capacity of FCSW: waste fiber delays the development of cracks to a certain extent, the shear capacity increases with the increase of waste fiber volume ratio, and decreases with the increase of recycled aggregate volume ratio.

(2) Based on the code for design of concrete structures, combined with the influence of volume ratio of waste fiber on shear capacity, the calculation formula of shear capacity of FCSW is proposed. By comparing with the test results, it can be found that the two formulas are in good agreement.

\section{Acknowledgments}

The study reported here is financially supported by Foundation of Henan Educational Committee (Grant No. 19A560025), National Natural Science Foundation of China (Grant No. U140454), Key Technologies R \& D Program of Henan Province(Grant No.182102210439). The support is gratefully acknowledged.

\section{References}

1. ZHANG D.(2012)The flexural properties' study of waste fiber recycled concrete beam [D]. Shenyang Jianzhu University.

2. GENG Y, WANG Q, Yuyin Wang etc. (2109)Influence of service time of recycled coarse aggregate on the mechanical properties of recycled aggregate concrete[J].Materials and Structures, Vol.52 (5), pp.1-16.

3. HANG $\mathrm{F} \mathrm{X}, \mathrm{CAO} \mathrm{X} \mathrm{Y}$, et al. Influence of admixture on compressive strength and splitting tensile strength of $\mathrm{C} 30$ recycled coarse aggregate self compacting concrete[J]. Concrete, (08) : 82-87.

4. WANG J Q.(2015) Testing Study on the Strength and Permeable Performance of $R$ ecycled
293.2

337.8

1.11

348.75

319.05

281.93

1.12

394.15

1.05

419.53

1.12
Aggregate Pervious Concrete. Structural engineers,31(04):167-171.

5. Mohammad S,Long S,Amir S, et al. (2019)Recycled concrete aggregate mixed with crumb rubber under elevated temperature[J]. Construction and Building Materials,222.119-129.

6. Wang $\mathrm{Y}$, Zureick A H, Cho B S, et al. (1994)Properties of Fiber Reinforced Concrete Using Recycled Fibers from Carpet Industrial Waste[J]. Journal of Materials Science,29(16):41914199.

7. ZHU H B, YAO C, ZHAO B L, et al. (2017)Experimental research on the effects of polypropylene fiber content on recycled concrete flexural fatigue performance[J]. Sichuan Building Science, 43(05):104-107.

8. YUAN F C, LI S.(2018)Review of fiber reinforced recycled aggregate concrete[J]. Concrete, (09):3139.

9. ZHOU J H, LIU Z H, LI T, et al. (2013)Experimental Study on Splitting Tensile Strength of Waste Fiber Recycled Concrete[J].Journal of Shenyang Jianzhu University ( Natural Science),29(5):796-802.

10. ZHOU J H, ZHAO W L, LIU D, et al. (2014)Damage analysis of waste fiber recycled concrete[J]. Concrete,(4):40-43.

11. ZHOU J H, LIU D, DONG J F.(2013)Constitutive relation of $\mathrm{W}$ aste fiber recycled concrete[J]. Concrete,(2):54-58.

12. ZHOU J H, ZHANG D, YANG Y S.(2013)Test Study on Flexural Properties of Waste Fiber Recycled Concrete Beams[J]. Journal of Shenyang Jianzhu University ( Natural Science), 29(2):290296.

13. WANG D L, LU Y L, YANG T.(2017)Experimental study on seismic behavior of recycled concrete frame joints with hybrid fibers[J]. WORLD EARTHQUAKE ENGINEERING, 33(01):117-121.

14. WANG J C, ZHOU J H, WANG $\mathrm{X}$ D, et al.(2018)Experimental study of the carbonation depth prediction model for waste fiber recycled concrete[J]. Industrial Construction, 28(3):17-20.

15. ZHANG W L. (2014)Experimental study on mechanical properties of waste fiber recycled concrete beam[D]. Shenyang Jianzhu University. 